\title{
THE DEVELOPMENT OF CROSS BORDER E-COMMERCE
}

\author{
Feng Ding \\ Tongji University, P.R.China \\ Jiazhen Huo \\ Tongji University, P.R.China \\ Juliana Kucht Campos \\ Technical University of Berlin, Germany
}

\begin{abstract}
Cross-border e-commerce is one type of international e-commerce similar to cross-border e-tailing. An increasing amount of people are shopping online across the borders, especially in China. By systematic review recent academic papers and research reports, the current situation of its development was identified. Supported by advanced technology, growing demand and advantageous policy, cross-border e-commerce is booming globally. However, culture and consumer behavior, laws and regulations, product and marketing issues, payment conditions and logistics limitations were identified as the main obstacles to its success. Because the products in cross-border e-commerce often require long distance transport, the logistics-related issues showed to be still the strongest concern to be addressed and overcome in order to allow such a movement, wherein, long transportation times, bad return service and high shipping costs are increasingly prominent. Therefore, a need for international cooperation between all involved parties - governments, merchants and service providers, is called. In the end, a proposed responsibility assignment for its development is presented.
\end{abstract}

Keywords: cross-border e-commerce, e-logistics, literature review.

\section{JEL code: L81, O30}

\section{Introduction}

E-commerce is the fastest growing area in the global economy, which short the distance between buyers and sellers. When online deals and transactions are conducted in different areas or countries by using information and communication technology (ICT), it is called cross-border e-commerce (CBE) (Wang, 2014; Accenture, 2012). Similar to cross-border e-tailing (Liu et al., 2015), CBE is a business to customer (B2C) process, used for integrating activities of suppliers and customers along the logistics value chain.

CBE has the potential to reduce trade barriers and promote trade growth (Terzi, 2011). According to the recent researches, the global business to customer (B2C) CBE market 
reached over $\$ 230$ billion in 2014 , and will further grow to $\$ 1$ trillion in 2020 (Erickson, 2015). By that year, nearly 1 billion people around the world are projected to be shopping online across the borders, and their transactions will account for one-third of all global B2C transactions (Accenture and AliResearch, 2015). (Figure 1)

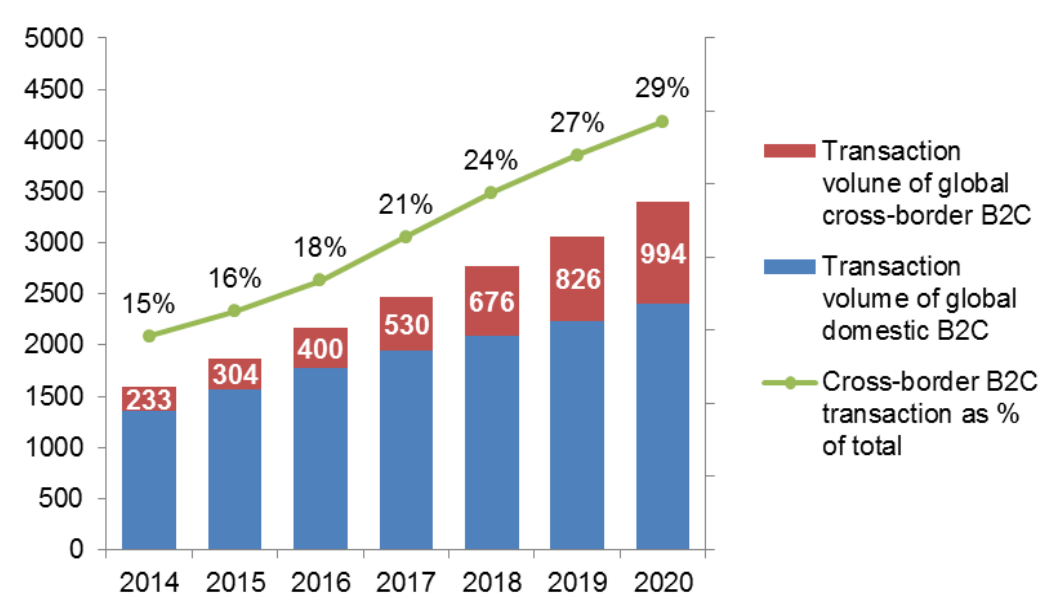

Figure 1. The global cross-border B2C volume (in \$ billions)

Because of superior infrastructure and regulation for e-commerce, Europe has a well-established cross-border shopping tradition. More than $25 \%$ online shoppers in the EU have made purchases from other countries (PRNewswire, 2015). And in 2018, B2C CBE sales in Europe will up to $€ 116$ billion (Statista, 2013). In the short term, CBE revenue will be concentrated in developed countries (UNCTAD, 2015), nevertheless in the long run, after the overcome of some information technology limitations, a leapfrog development is expected by developing countries (JLL, 2013; Panagariya, 2000). For instance, in China, the gross merchandise volume (GMV) of CBE is expected to contribute over $20 \%$ of total foreign trade volume in 2017 (Liu et al., 2015). China will become the largest CBE market by 2020 (Accenture and AliResearch, 2015).

With the continued growth of cross-border e-commerce, a need for comprehensive and in-depth study on it is required. This paper will present more details about the drivers, barriers and trends of its development by reviewing recent academic papers and research reports, as well as address recommendations for future collaborative initiatives.

\section{The drivers of CBE development}

\subsection{Advanced technology}

Globalization refers to the growing volume and variety of cross-border transactions in goods and services through the rapid and widespread diffusion of technology (Pounder, 2013). Advanced e-commerce technologies reduce marketing costs and administration expenditures, while enabling companies to reach dispersed markets (Burinskiene, 2012; Grant and Bakhru, 2004; Shama, 2005). The fast paced internet has brought a large growth of online shopping users (Okamura, 2006), and expanded international business market (Hwang et al., 2006; I-Ways, 2003; Panagariya, 2000; Shewmake and Sapp, 2000). The combination of Internet 
and foreign trade supported the CBE development. From consumers' perspective, the developed technologies allowed them to cross invisible borders to shop online more easily (Alkadi et al., 2004), such as convenient cross-border payment (McDermott, 2015) and growing usage of smart mobile (Marceux, 2015).

\subsection{Growing demand}

In an era of e-commerce and international businesses, a company's operational model must be build based on the customers' requirements (Lee et al., 2010). For consumers in developing countries, poorer quality, counterfeit goods and product piracy stimulate them to purchase goods gradually frequently from abroad (Analysys, 2015; DHL, 2013; Forrester, 2014). In China, the generations born in the 80s and 90s from the middle class have become the main consumer groups and with more intentions of shopping online from abroad (Tentinet, 2015; Voyageone, 2015). However, the lack of products' availability and better prices in foreign market are still the most cited triggers for cross-border online shopping.

\subsection{Advantageous policy}

Trade liberalization increased exports of goods and services to new markets, for instance, the establishment of European Free Trade Agreement and China Free Trade Area. Previously, such trade was not feasible due to the net effect of import tariffs made being competitive in foreign markets improbable (Pounder, 2013). The advantageous policies will open up markets for trades, including those from developing countries (Nielson and Morris, 2001). The Chinese government introduced a series of favorable policies for CBE (Analysys, 2015; CECRC, 2015), established several free trade zones to lower the duties and concise customs clearance procedures (CECRC, 2015; PwC, 2015), which have boosted foreign cross-border sales (McDermott, 2015).

\section{The barriers for implementing CBE}

After an extensive complete review of the latest papers and reports (Appendix), six categories of barriers for implementing CBE were identified. (Figure 2)

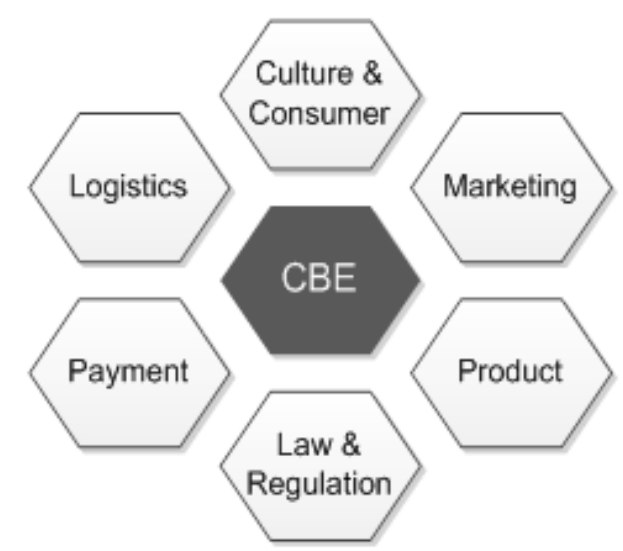

Figure 2. The main barriers for cross-border e-commerce 


\subsection{Culture and Consumer}

At first, the flows of information and goods cross borders and encounter cultural differences along the way. The typical difference is language, which can change the distribution culture of that market and hinder consumers' consumption from abroad (Youngdahl and Loomba, 2000). Secondly, consumer behaviors are different according to countries, more information about commodities preferences, delivery and online payment options of foreign consumer, are especially needed. Finally, the merchants' reputation is showed to be an important factor during decision making with most consumers concerning about the reliability of international delivery and online payments.

\subsection{Marketing}

Commonly e-commerce businesses struggle to find adequate information about foreign market operation. For brands that are relatively unknown in target markets, the cost of building brand awareness turns to be high, such as advertising through multi-channel. Additionally, global markets place businesses have been continuously extending their operations overseas, posing a threat to domestic e-commerce enterprises (Liu et al., 2015).

\subsection{Product}

Consumers lack of trust towards cross-border sellers is frequently cited as one of the challenges due to fake and counterfeit goods, which are most commonly observed in emerging markets. Additionally, due to the high standardization, popularity and profitability, some commodities such as computer, communication and consumer electronic products are very suitable for cross-border e-commerce, resulting in a serious homogenization of competition.

\subsection{Law and Regulation}

Different laws and regulations between countries limit the ability of cross-border business, such as data privacy and return police. The customers can unconditionally return online purchase within 7 days after received in Germany, but only 7 days in China. Furthermore, when consumers choose purchase abroad, duties must be considered taking into account the total cost. High tariffs, taxation limits and VAT thresholds often reduce cross-border purchasing intentions.

\subsection{Payment}

In order to make buying online more attractive to consumers from target markets, e-retailers have to be familiar with local payment preferences. For example, in Russia, it is still very common to pay in cash upon receipt of the goods, whereas this rarely happens in Western countries. Moreover, the unavailability to use local currency, complex conversion systems, exchange rate fluctuations and additional depreciation also harder cross-border shopping and 
increase the consumers' costs. Lastly is the lack of effective surveillance system. Fraud and non-payment result in enormous losses for e-commerce merchants, while customers worry about misuse of payment data and disclosure of personal information.

\subsection{Logistics}

First, the basic logistics' infrastructure, such as highways, railways and also warehouses, are considered underdeveloped in some countries. The outdated customs system and complicated clearance procedures are general problem for all international trade. The extra costs incurred cam make the operation of small e-retailers unfeasible. Once the CBE delivery requires long distances through different countries, extensive time and untimely delivery, uncertain or non-delivery, are observed as the largest obstacles in the delivery process. Besides, difficulties are also cited regarding specific requirements from different countries, e.g. incompatible addressing systems. For the same reason, long distance shipping in cross-border e-commerce generates higher costs compared to domestic delivery. Moreover, delivery information allows customers to take control over receiving or collecting their goods, limited transparency and different information systems make tracking online orders of international transport more difficult. Finally, infeasible and inefficient international return processes result in customer dissatisfaction.

From 24 studies (Appendix), 22 (92\%) mentioned logistics as the main challenge for implementing CBE due to its complexity and higher cost (IPC, 2010). Specifically, long transportation times (64\%), bad return service (50\%), and high shipping costs (36\%) are key problems. For some authors, logistics' barriers may impede the successful development of global-businesses and also international e-commerce (JLL, 2013; Xu et al., 2002).

The rise of e-commerce and globalization has changed consumption patterns. The logistics system should be designed to meet needs for small, diverse, and high frequency pickups and deliveries at different locations, in different packaging, according to different schedules and stringent customer service requirements (Hu et al., 2015; Samiee, 2008; Tarn et al., 2003).

\section{The trends of CBE development}

\subsection{Service competition}

In the early days of cross-border e-commerce, merchants are primarily competing in products. With the development of internet technology and supply chain optimization, this competition is turning to service level (Analysys, 2015). Those capable to provide convenient and fast service will reach competitive advantage and consumers' loyalty.

\subsection{One-stop service}

Brand merchants or those with larger online volumes often have their own fulfillment facilities. However, for small and medium enterprises (SMEs), there is a demand for 
integrated solutions, such as global online marketplace (Forrester, 2014). Some provide a full range of one-stop services: payment processing, customer services, shipping, clearance, return processing and delivery, such as Amazon.com and Alibaba.com (UNCTAD, 2015).

\subsection{Omni-channel}

Besides pure online retailers, traditional retailers and even producers are also showing interest in developing international online channels. Meanwhile, mobile commerce continues to grow, smartphone and tablet are becoming another channel for cross-border shopping (McDermott, 2015). The ultimate evolution of multi-channel and cross-channel retail is "Omni-channel" retail. Where, consumers are able to access the retailers from any platform (DHL, 2015b).

\section{Recommendations and proposed solutions}

\subsection{Government's support}

Government plays a key role to solve the above-mentioned problems through the investment in logistics' infrastructure, positive legislation for facilitating customs clearance and combating counterfeit products. These measures will dramatically promote the cross-border e-commerce trade.

From 2013, the Chinese government released a series of policies to facilitate CBE involving supervision, payment, settlement and implementation (iResearch, 2015). With the approval of seven new free trade zones (FTZ), the total number will be up to 11, they are Shanghai, Tianjin, Fujian, Guangdong, Liaoning, Zhejiang, Henan, Hubei, Sichuan, Shaanxi and Chongqing (CRIENGLISH, 2016) (Figure 3). More favorable conditions and policies are provided for international trade in FTZ, such as greatly simplifies the administrative approval process and cutting customs clearance times. FTZ is considered as one of the responsible methods for promoting foreign cross-border sales into China (McDermott, 2015).

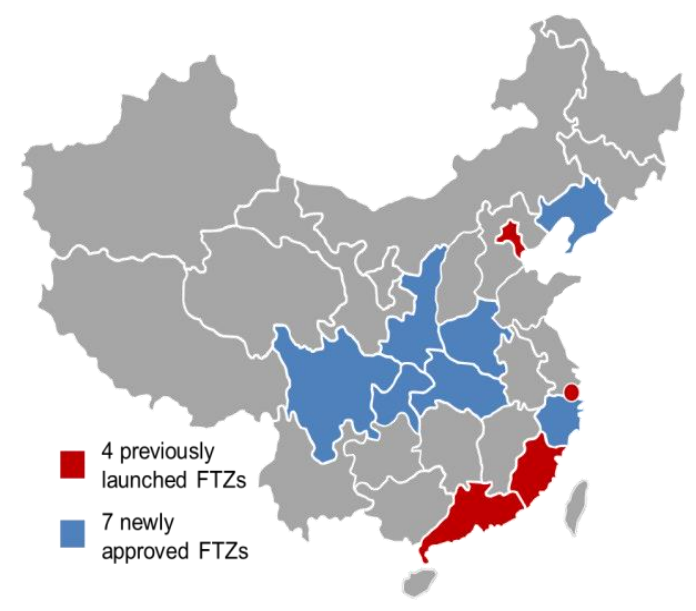

Figure 3. Free trade zones in China

Similarly is the European Free Trade Agreement, where all member states of the European Union (EU) form a customs territory (the European Customs Union) where unified customs 
arrangements are applied. Goods imported into the EU are subject to EU-wide import regulations, customs tariffs and customs procedures. Compared to China, Europe forms a large free trade zone (Figure 4), where customs duties are only levied when the goods are imported into the EU. Once goods have been imported into the EU, no further customs duties must be paid within the customs territory - even if the goods cross internal borders of member states (GTAI, 2016). Individual postal products (online procurement) which are sent from Non-EU and the total value below 22 euros are admitted free of import duties. The others need to pay a $19 \%$ VAT according to customs regulations of EU Member States (ZOLL, 2016).

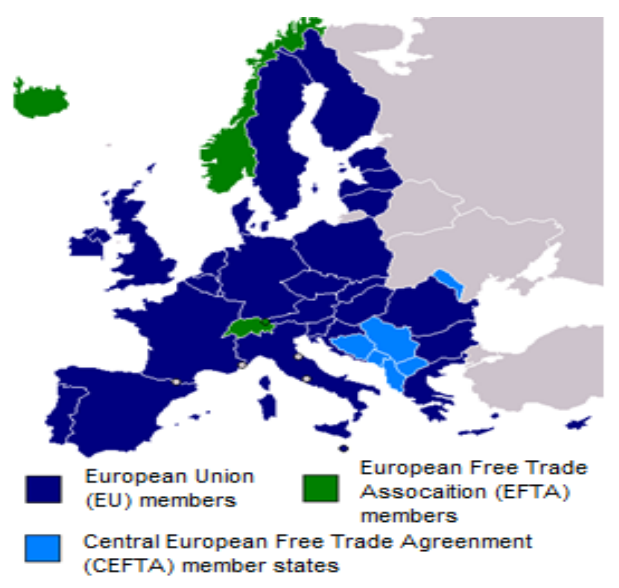

Figure 4. Free trade areas in Europe

\subsection{Merchants' localization}

Different cultures and policies from different countries lead inevitably to specific consumer behavior, such as payments and goods preference. Merchants need to take local characteristics into account when designing CBE operations (Reynolds, 2001).

- Add local-language version of website (Alkadi et al., 2004). English websites are already standard in Europe. Some European e-retailers already set up a webpage in Chinese.

- Extend local payment options. Globally, credit cards are widely popular, but some countries have distinctly local preferences, such as AliPay in China, Sofort in Germany and cash in many Eastern European markets (McDermott, 2015). It is critical to consider the local payment set-up in order to improve customer satisfaction.

- Use local popular channels. If brands are relatively unknown in a new market, the usage of local social media and search engine, are effective methods for image awareness improving fleetly (Froelich, 2014).

- Set up domestic service center. The establishment of call centers in target market, aligned with after-sale services support companies maintaining similar service levels as they are used to in domestic market (Ecommerce Europe, 2015)

Lack of information about foreign market can limit business expanding. If merchants do not have the ability or the capital to develop localization strategies, cooperating with third party service providers might be an efficient alternative. 


\subsection{Service providers' assistance}

Identifying the right partner enables merchants to access to international markets easily and rapidly (McDermott, 2015; Reynolds, 2001), and support them with the following aspects:

- Payment service. Simplify the process of currency conversion and tax calculation, establish connections with multiple payment options, improve security and reduce fraud (Froelich, 2014).

- Marketing service. Understand local consumers and legal issues, find potential products, view pricing in preferred currencies, support check out online with the payment customers prefer (Pitney Bowes, 2010).

- Logistics service. Provide global coverage, delivery speed/consistency and competitive costs. In addition, logistics service providers (LSPs) can support calculating taxes and duties, filling out paperwork and simplifying cross-border returns (Forrester, 2014).

\section{Conclusion}

Through a systematic review of recent articles and research reports, the main drivers, barriers and trends for cross-border e-commerce development were presented. Advanced technology, growing demand and advantageous policies were identified as the promoting factors, meanwhile, issues about culture and consumer behavior, marketing, product, laws and regulations, payment and logistics were observed as the main barriers to its success, wherein, logistics-related issues showed to be still the strongest concern to be addressed (Pitney Bowes, 2010). Therefore, a need for international cooperation between all involved parties governments, merchants and service providers, is called (Figure 5).

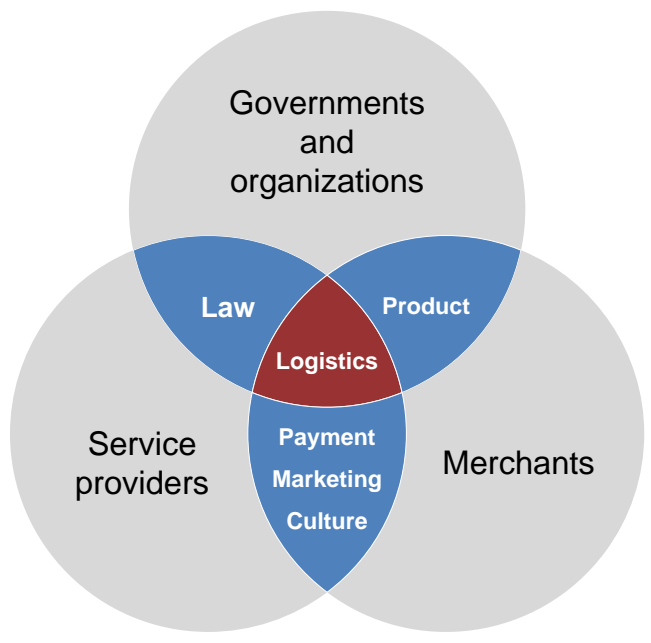

Figure 5. A responsibility assignment for cross-border e-commerce development

Governments and organizations should release a series of favorable policies for CBE development, such as lowering the duties and simplifying customs clearance procedures, as well setting stringent regulations to combat counterfeit products. Besides the government responsibility, merchants are demanded to strengthen their own quality control for reducing product defects and e-marketplaces to ensure that the joined merchants fill the strict qualifications. Moreover, the identification of potential products to avoid commodities 
homogenization can improve enterprises' market competitiveness. However, it is clear the challenge of overcoming the lack of adequate information about foreign market operations. The author's proposition is to cooperate with third party service providers, who can support the market exploitation and improve brand awareness, handle with international payment and reduce chances of fraud. It requires service providers to be familiar with local laws and regulations, culture and consumers behavior. In order to improve international customers' satisfaction and loyalty, improvement in logistics operations are demanded. Investments in infrastructure by the government, efficient international logistics from services providers, convenient return and after-sales service from merchants need to be aligned. A successful and integrated solution is, for instance a government-led marketplace such as "Kuajingtong.cn" in the Shanghai free trade zone (KJT, 2016).

In order to achieve "the right product at the right place at the right time cross the border", there are a number of approaches and systems which have been designed and implemented to improve logistics operations (Ho et al., 2012). However, an effective global e-logistics system is still required more in-depth study and investigation. This offers an opportunity to improve the efficiency of e-logistics system in cross-border relations in future studies.

\section{References}

Accenture, (2012) European Cross-border E-commerce: The Challenge of Achieving Profitable Growth, Dublin: Accenture Publications.

Accenture and AliResearch, (2015) The prospect for the global cross-border B2C e-commerce market, Beijing: AliResearch Publications.

Adyen, (2015) Cross-Border Payments-Opportunities and Best Practices For Going Global, San Francisco: Adyen Publications.

Alkadi, I., Alkadi, G. and Zhu, Z. (2004) "Growth of international franchising through E-Commerce”, Human Systems Management, vol. 23, pp.269-273.

Analysys, (2015) The research report of China's cross-border import e-commerce market, Beijing: Analysys Ltd. Publications.

Burinskiene, A. (2012) "International trade and E-commerce in the practice of enterprises activity”, European Integration Studies, vol. 6, pp.85-93.

Carlton mansfield, (2015) Research on Cross BorderE-Commerce \& Free Trade Zone, Hong Kong: Carlton Mansfield Publications.

China Ecommerce Research Center (CECRC), (2016) The monitoring report of China's e-commerce market data in 2015, Hang Zhou: CECRC. 
Colliers, (2015) Crossing Borders, Changing Times-A new model for international e-commerce has strong implications for China's bonded logistics property market, Shanghai: Colliers international Publications.

CRIENGLISH, (2016) "China decides to add 7 new free trade zones", [Online], Available: http://www.scio.gov.cn/32618/Document/1489719/1489719.html (1 September 2016)

DHL, (2015a) Cross border E-commerce-An operator's perspective, Königswinter: DHL Publications.

DHL, (2015b) Insight on E-Commerce \& Collaboration, Brussels: DHL Publications.

DHL, (2013) Shop the world!-Consumer attitudes towards global distance selling, Bonn: Deutsche Post AG Publications.

Ecommerce Europe, (2015) e-Logistics: A need for integrated European solutions, Brussels: Ecommerce Europe Publications.

Erickson, J. (2015) “Cross-Border E-Commerce To Reach \$ 1 Trillion In 2020”, [Online], Available: http://www.alizila.com/cross-border-e-commerce-to-reach-1-trillion-in-2020/ (11 June 2015)

Forrester, (2014) Seizing The Cross-Border Opportunity Businesses Can Go Global, Cambridge: Forrester Publications.

Froelich, I. (2014) Preparing your organization for cross-border ecommerce, Amsterdam: Payvision Publications.

Germany Trade \& Invest (GTAI), (2016) "Customs and Import Arrangements", [Online], Available:http://www.gtai.de/GTAI/Navigation/EN/Invest/Investment-guide/The-tax-system/c ustoms.html (11 March 2016)

Gordon, J. (2014) EU-China E-Commerce Development, Europe: Europe China Research and Advice Network Publications.

Grant, R.M. and Bakhru, A. (2004) "The limitations of internationalisation in e-commerce", European Business Journal, vol. 16, pp.95-104.

Ho, G.T.S., Choy, K.L., Lam, C.H.Y. and Wong, D.W.C. (2012) "Factors influencing implementation of reverse logistics: a survey among Hong Kong businesses", Measuring Business Excellence, vol.16, pp.29-46.

Hu, Y.C., Chiu, Y. J., Hsu, C.S. and Chang, Y.Y. (2015) "Identifying Key Factors for Introducing GPS-Based Fleet Management Systems to the Logistics Industry", Mathematical 
Problems in Engineering, vol. 8, pp.1-14.

Hwang, W., Jung, H.S. and Salvendy, G. (2006) "Internationalisation of e-commerce: a comparison of online shopping preferences among Korean, Turkish and US populations", Behavior \& Information Technology, vol. 25, no.1, pp.3-18.

I-Ways, (2003) "Impacts of E-Commerce in the Global Networked Economy", Digest of Electronic Commerce Policy and Regulation, vol. 26, no.4, pp.171.

International Post Corporation (IPC), (2010) Cross-Border E-Commerce Report, Belgium: International Post Corporation Publications.

iResearch, (2015) 2014 China Cross-border E-commerce Report (Brief Edition). Shanghai: iResearch Publications.

JLL, (2013) E-commerce boom triggers transformation in retail logistics, New York: JLL Publications.

KJT, (2016) “KJT help content-about us", [Online], Available: http://www.kjt.com/helpc ontent/196 (9 July 2016)

Kommerskollegium, (2012) E-commerce-New Opportunities, New Barriers, Sweden: Kommerskollegium Publications.

Lee, C.H., Huang, S.Y., Barnes, F.B. and Kao, L. (2010) "Business performance and customer relationship management: The effect of IT, organisational contingency and business process on Taiwanese manufacturers", Total Quality Management, vol.21, no.1, pp.43-65.

Landmark global (LG), (2015) White paper e-commerce: Rethinking distribution networks, Santa Barbara: Landmark global Publications.

Liu, X., Chen, D. and Cai, J. (2015) "The Operation of the Cross-Border e-commerce Logistics in China", International Journal of Intelligent Information Systems, vol.4, no.2, pp.15-18.

Marceux, P. (2015) "What are the Main E-Commerce Drivers in Emerging Markets?", [Online], Available: http://blog.euromonitor.com/2015/09/what-are-the-main-e-commerce-dr ivers-in-emerging-markets.html (21 September 2015)

McDermott, K. (2015) Key Business Drivers and Opportunities in Cross-Border Ecommerce, Amsterdam: Payvision Publications.

Nielson, J. and Morris, R. (2001) "E-commerce and trade: resolving dilemmas", OECD Observer, vol. 224, pp.37-39. 
Okamura, J. (2006) "Worldwide via the Web", Multi-channel Merchant (Penton Media, Inc.), vol.2, no.2, pp.31-32.

Panagariya, A. (2000) "E-Commerce, WTO and Developing Countries", World Economy, vol.23, no.8, pp.959-978.

Paypal, (2014a) Unlocking the cross-border trade opportunity, San Jose: Paypal Publications.

Paypal, (2014b) Cross-Border Research 2014-Global snapshot, San Jose: Paypal Publications.

Paypal, (2013) Modern Spice Routes-The Cultural Impact and Economic Opportunity of Cross-Border Shopping, San Jose: Paypal Publications.

Pitney Bowes, (2010) Time to Get Serious About Cross-Border Ecommerce, Stamford: Pitney Bowes Publications.

Pounder, P. (2013) “A Review of Supply Chain Management and Its Main External Influential Factors in the global market economy Supply Chain", Supply Chain Forum, vol.14, no.3, pp.42-50.

PRNewswire. (2015) "Global Cross-Border B2C E-Commerce 2015”, [Online], Available: http://www.prnewswire.com/news-releases/global-cross-border-b2c-e-commerce-2015-30015 6055.html (7 October 2015)

PwC, (2015) China to open up its import tariff and importation policies for consumer products, Hong Kong: PwC Publications.

Reynolds, J. (2001) Logistics and Fulfillment for E-Business (1st ed), New York: CRC Press.

Samiee, S. (2008) "Global marketing effectiveness via alliances and electronic commerce in business-to-business markets”, Industrial Marketing Management, vol.37, no.1, pp.3-8.

Shama, A. (2005) "An empirical study of the international marketing strategies of e-commerce companies", Thunderbird International Business Review, vol.47, no.6, pp. 695-709.

Shewmake, B. and Sapp, G. (2000) "Bringing down the international barriers", Info World, vol. 22, no.18, pp.30.

Tam, J.M., Razi, M.A., Wen, H.J. and Jr, A.A.P. (2003) "E-fulfillment: the strategy and operational requirements" Logistics Information Management, vol.16, no.5, pp:350-362. 
Tentinet, (2015) Research Report on China's Cross-border E-commerce in 2015, Shen Zhen: Tentinet Publications.

Terzi, N. (2011) "The impact of e-commerce on international trade and employment," Procedia - Social and Behavioral Sciences, vol. 24, pp.745-753.

UNCTAD, (2015) Information Economy Report 2015: Unlocking the Potential of E-commerce in Developing Countries, New York: UNCTAD Publications.

van Heel, B., Lukic, V. and Leeuwis, E. (2014) "Cross-Border E-Commerce Makes th e World Flatter" , [Online], Available: https://www.bcgperspectives.com/content/articles/tr ansportation_travel_tourism_retail_cross_border_ecommerce_makes_world_flatter/[18 Sept ember 2014]

Visser, J., Nemoto, T. and Browne, M. (2014) "Home Delivery and the Impacts on Urban Freight Transport: A Review", Procedia - Social and Behavioral Sciences, vol. 125, pp.15-27.

Voyageone, (2015) Strategies to drive cross-border E-commerce growth in China, Shanghai: Voyageone Publications.

Wang, J. (2014) "Opportunities and Challenges of International e-Commerce in the Pilot Areas of China”, International Journal of Marketing Studies, vol. 6, no.6, pp.141-149.

$\mathrm{Xu}$, K., Wilkinson, T. and Brouthers, L.E. (2002) "The Dark Side of International E-Commerce: Logistics. Mark”, Marketing Management Journal,vol.12, no.2, pp.123-134.

Youngdahl, W.E. and Loomba, A.P.S. (2000) "Service-driven global supply chains," International Journal of Service Industry Management, vol.11, no.4, pp. 329-347.

ZOLL, (2016) "Consignments of negligible value”. Generalzolldirektion. [Online], Available: http://www.zoll.de/EN/Private-individuals/Postal_consignments_internet_order/Shipments-toGermany/Duties-and-taxes/Consignments-of-negligible-value/consignments-of-negligible-val ue.html [18 July 2016] 


\section{Appendix}

List of studies on cross-border e-commerce and mentioned barriers for its development

\begin{tabular}{|c|c|c|c|c|c|c|c|}
\hline Author/Institution & Year & $\begin{array}{l}\text { Culture \& } \\
\text { Consumer }\end{array}$ & Marketing & Product & $\begin{array}{l}\text { Laws \& } \\
\text { regulations }\end{array}$ & Payment & Logistics \\
\hline Accenture & 2012 & $\mathrm{x}$ & $\mathrm{x}$ & & $\mathrm{x}$ & $\mathrm{x}$ & $\mathrm{x}$ \\
\hline Adyen & 2015 & & & & & $\mathrm{x}$ & \\
\hline Carlton mansfield & 2015 & & & $\mathrm{x}$ & & & $\mathrm{x}$ \\
\hline Colliers & 2015 & & & & & & $\mathrm{x}$ \\
\hline DHL & 2013 & $\mathrm{x}$ & & $\mathrm{x}$ & & $\mathrm{x}$ & $\mathrm{x}$ \\
\hline DHL & $2015 a$ & $\mathrm{x}$ & $\mathrm{x}$ & & & $\mathrm{x}$ & $\mathrm{x}$ \\
\hline DHL & $2015 b$ & & & & & & $\mathrm{x}$ \\
\hline Ecommerce Europe & 2015 & & & & $\mathrm{x}$ & & $\mathrm{x}$ \\
\hline Forrester & 2014 & $\mathrm{x}$ & & & $\mathrm{x}$ & $\mathrm{x}$ & $\mathrm{x}$ \\
\hline Froelich, I. & 2014 & $\mathrm{x}$ & $\mathrm{x}$ & & $\mathrm{x}$ & $\mathrm{x}$ & $\mathrm{x}$ \\
\hline Gordon, J. & 2014 & & & & & & $\mathrm{x}$ \\
\hline IPC & 2010 & $\mathrm{x}$ & $\mathrm{x}$ & & & $\mathrm{x}$ & $\mathrm{x}$ \\
\hline iResearch & 2015 & & $\mathrm{x}$ & $\mathrm{x}$ & & & $\mathrm{x}$ \\
\hline JLL & 2013 & & & & & & $\mathrm{x}$ \\
\hline Kommerskollegium & 2012 & & $\mathrm{x}$ & & $\mathrm{x}$ & $\mathrm{x}$ & $\mathrm{x}$ \\
\hline LG & 2015 & & & & & $\mathrm{x}$ & $\mathrm{x}$ \\
\hline McDermott, K. & 2015 & $\mathrm{x}$ & & & $\mathrm{x}$ & $\mathrm{x}$ & $\mathrm{x}$ \\
\hline Paypal & 2013 & & & & & $\mathrm{x}$ & \\
\hline Paypal & $2014 \mathrm{a}$ & & & & & $\mathrm{x}$ & $\mathrm{x}$ \\
\hline Paypal & $2014 b$ & & & $\mathrm{x}$ & $\mathrm{x}$ & & $\mathrm{x}$ \\
\hline Pitney Bowes & 2010 & $\mathrm{x}$ & & & $\mathrm{x}$ & $\mathrm{x}$ & $\mathrm{x}$ \\
\hline Tentinet & 2015 & & $\mathrm{x}$ & $\mathrm{x}$ & $\mathrm{x}$ & $\mathrm{x}$ & $\mathrm{x}$ \\
\hline UNCTAD & 2015 & & & & $\mathrm{x}$ & & $\mathrm{x}$ \\
\hline van Heel et al. & 2014 & & & & & & $\mathrm{x}$ \\
\hline
\end{tabular}

